\title{
Inter-sectorial network for assisting women in situations of violence: handicraft work built by the people
}

\author{
Rede intersetorial de atendimento às mulheres em situação de violência: trabalho artesanal construído pelas pessoas
}

Red intersectorial de atención a mujeres en situación de violencia: trabajo artesanal construido por las personas

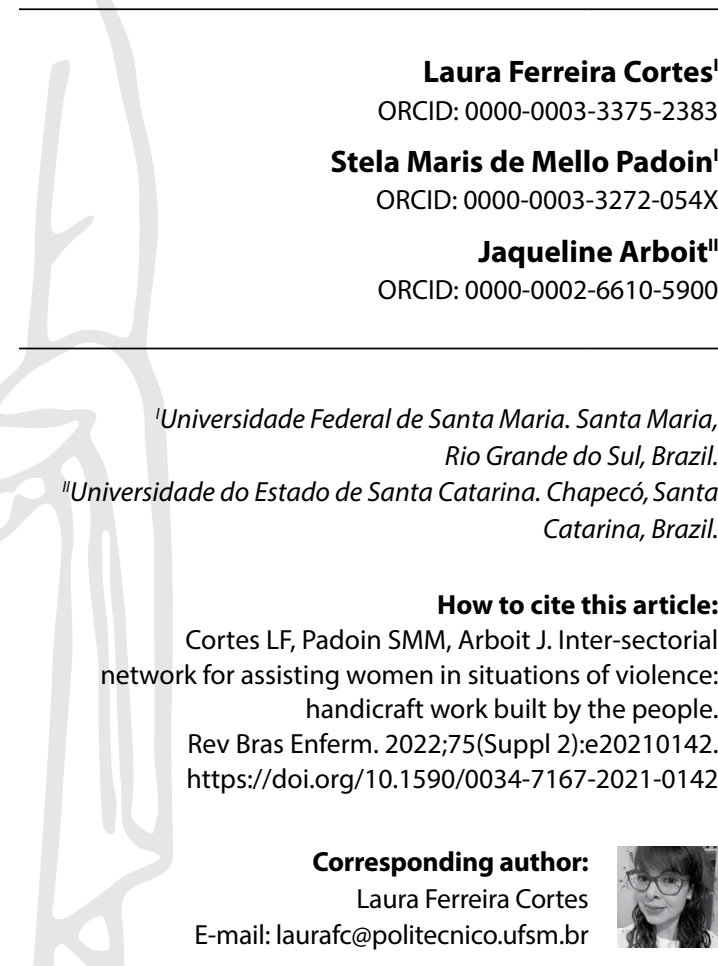

EDITOR IN CHIEF: Antonio José de Almeida Filho ASSOCIATE EDITOR: Fátima Helena Espírito Santo

Submission: $03-26-2021$

Approval: 09-13-2021

\begin{abstract}
Objectives: to discuss the meanings attributed by professionals to the construction of the service network for women in situations of violence. Methods: Convergent Care Research developed with the application of a convergence group with 32 participants from the health, social assistance, or public security sectors, in Santa Maria, Rio Grande do Sul. The data was produced during ten meetings, based on the problematization methodology, and submitted to analysis of thematic content and interpreted with the referential of networks. Results: the construction of the network is an artisanal work carried out by people continuously, permeated by bonds, communication and partnerships between services and knowledge of work processes. Lashings require permanent movement. Final Considerations: building a network implies defining intertwining lines; form nodes that create cross-sector connections. There is a need to institutionalize processes through care continuity protocols, associated with an efficient communication system between sectors.

Descriptors: Intimate Partner Violence; Gender-Based Violence; Intersectoral Collaboration; Comprehensive Health Care; Nursing.
\end{abstract}

\section{RESUMO}

Objetivos: discutir os sentidos atribuídos por profissionais à construção da rede de atendimento às mulheres em situação de violência. Métodos: Pesquisa Convergente Assistencial desenvolvida com aplicação de grupo de convergência com 32 participantes de setores da saúde, assistência social ou segurança pública, em Santa Maria, Rio Grande do Sul. Os dados foram produzidos durante dez encontros, pautados na metodologia da problematização, submetidos à análise de conteúdo temática e interpretados com o referencial de redes. Resultados: a construção da rede é um trabalho artesanal realizado pelas pessoas continuamente, permeado por vínculo, comunicação e parcerias entre os serviços e conhecimento dos processos de trabalho. As amarrações exigem movimento permanente. Considerações Finais: construir rede implica definir linhas que se entrelaçam; formar nós que criam conexões intersetoriais. Há necessidade de institucionalização dos processos por meio de protocolos de continuidade do cuidado, associados a um sistema de comunicação eficiente entre os setores.

Descritores: Violência por Parceiro Íntimo; Violência de Gênero; Colaboração Intersetorial; Assistência Integral à Saúde; Enfermagem.

\section{RESUMEN}

Objetivos: discutir los sentidos atribuidos por profesionales a construcción de la red de atención a mujeres en situación de violencia. Métodos: Investigación Convergente Asistencial desarrollada con aplicación de grupo de convergencia con 32 participantes de sectores de salud, asistencia social o seguridad pública, en Santa Maria, Rio Grande do Sul. Datos fueron producidos durante diez encuentros, pautados en la metodología de la problematización, sometidos al análisis de contenido temático e interpretados con el referencial de redes. Resultados: la construcción de la red es un trabajo artesanal realizado por personas continuamente, permeado por vínculo, comunicación y colaboraciones entre los servicios y conocimiento de los procesos de trabajo. Las amarraduras demandan movimiento permanente. Consideraciones Finales: construir red implica definir líneas que se entrelazan; formar nudos que crean conexiones intersectoriales. Hay necesidad de institucionalización de los procesos mediante protocolos de continuidad del cuidado, asociados a un sistema de comunicación eficiente entre los sectores.

Descriptores: Violencia de Pareja; Violencia de Género; Colaboración Intersectorial; Atención Integral de Salud; Enfermería. 


\section{INTRODUCTION}

Gender violence is a public health problem that violates women's human rights and constitutes a challenge for gender equality, contributing to the legitimacy of social domination based on the understanding of women as inferior being $\mathrm{s}^{(1)}$. It has a high worldwide prevalence ${ }^{(2)}$, serious consequences for health, health, social and economic impacts ${ }^{(3)}$.

It is estimated that, worldwide, $30 \%$ of women have already experienced some situation of physical or sexual violence at some point in their lives ${ }^{(2)}$. In Brazil, a national survey found an increase in the percentage of women who claimed to have suffered some type of violence, which rose from 18\% in 2015 to $29 \%$ in 2017. The most cited types were: physical violence (67\%), psychological $(47 \%)$ and moral $(6 \%)$ and sexual $(15 \%)^{(4)}$.

Intimate partner violence (IPV) is also based on gender inequalities, which are a marker of social inequality. It is anchored in widespread cultural and social norms that support the gender roles of men and women and are used to justify and normalize violence ${ }^{(5)}$. In Brazil, public policies to combat violence against women $^{(6-7)}$ recognize gender as a transversal determinant, as well as the diversity between them and their various vulnerabilities.

When analyzed using the color/ethnicity marker, it is clear that gender violence is more prevalent in black women (brown and black). In 2017, in Brazil, $66 \%$ of murdered women were black. This highlights the great difficulty of the Brazilian State in guaranteeing the universality of its public policies ${ }^{(8)}$; and emphasizes the importance of addressing gender violence in an intersectional way, in order to articulate gender with the various forms of oppression ${ }^{(9)}$. It is believed that recognizing this diversity is essential to support the planning of actions in an inter-sectorial network, based on the life contexts of women who experience the event differently.

The social and economic impacts of the problem are related to the decrease in productivity and wages, which affects not only women in this situation, but also the country's economy in both the public and private sectors. In the context of health, there is evidence of biological, neurological, psychological and behavioral impacts for women who experience violence and for their families, configuring a health risk factor ${ }^{(3)}$. Some of these consequences are depressive ${ }^{(10)}$ and anxiety ${ }^{(11)}$ disorders, abortion $^{(11-12)}$, sexually transmitted infections, unwanted/unplanned pregnancy ${ }^{(12)}$ and lower quality of life ${ }^{(13)}$; also, low self-esteem, family and social isolation ${ }^{(14)}$, as well as the consumption of legal and illegal substances ${ }^{(2)}$. IPV is also directly related to lower wellbeing of children ${ }^{(15)}$.

Thus, there is a multifactorial complexity and causality of the problem, requiring actions beyond identification and referrals ${ }^{(16)}$ and transcending situations marked by the biomedical paradigm that produces fragmented and sectored care practices. It is necessary to overcome the punctual attention to these women - in general, focused on the physical marks of the violence experienced. There is a lack of follow-up of cases, need for intersectoral action in a network and qualifying protocols for care $\mathrm{c}^{(3,17-18)}$.

The psychosocial demands and other various needs derived from the systematic disrespect for human rights, citizenship, as well as the consequent high vulnerability of these women, provide a set of harms. From this perspective, the National Policy for Combating Violence against Women defines an "intersectoral network for assisting women in situations of violence" as a set of actions and services from different sectors, in particular, social assistance, health, justice and public security, that aim at expanding and improving the quality of care; identification and proper referral of women; and the comprehensiveness and humanization of care. The Policy proposes the prevention axes; confrontation and combat; assistance; and guaranteeing women's rights. It advocates actions that deconstruct inequalities; combat gender discrimination in order to interfere with sexist cultural patterns; promote women's empowerment; and guarantee a qualified service ${ }^{(6)}$.

The logic of networking has been considered the best strategy for dealing with the problem. It demands an articulated set of intersectoral actions ${ }^{(1,18-21)}$, in which services can form an integrated whole.

In this sense, there are studies that address the service network for confronting violence against women, especially IPV, in its conceptualization, composition and intersectoral articulation ${ }^{(17-18,21-22)}$. It is composed from a set of different sectors, especially: social assistance, health, justice and public security, which aim to expand and improve the quality of care; identification and proper referral of women ${ }^{(6)}$.

Among the multiple meanings of the term "network", the one that alludes to the network as an object stands out, that is, a continuity of lines that intersect and intertwine, passing through nodes and creating links between them, connections. The network is characterized by the absolute dependence of all nodes on each other ${ }^{(23)}$. In this study, this metaphor was adopted, which brings the image of lines that are strongly connected by "us", the care services - in addition to the meaning of a network linked to inter-sectorial communication, based on the National Policy ${ }^{(6)}$.

It is necessary to consider the need for dialogue between professionals from different sectors so that the network is woven by the protagonists of actions to combat IPV. With this perspective and anchored in the methodological framework of the Convergent Care Research ${ }^{(24)}$, this investigation had as a study question: What are the meanings attributed by professionals to the construction of the care network for women in situations of violence?

\section{OBJECTIVES}

To discuss the meanings attributed by professionals to the construction of the service network for women in situations of violence.

\section{METHODS}

\section{Ethical aspects}

To meet the requirement to preserve the anonymity of the participants, referred to in Resolution No. 466/2012, which defines standards for research with human beings in Brazil, the statements were coded with the letter $P$ followed by a number and the service to which they were linked ( $p$.ex., P1/Municipal Health Department). The sessions of the convergent group were 
audio-recorded, lasting approximately two hours. The study was approved by the Research Ethics Committee of the institution.

\section{Theoretical-methodological framework and type of study}

Participatory research, with a qualitative approach, of the Convergent Care Research (CCR) type. CCR is a method that was developed by Brazilian researchers in the field of nursing, whose essence is linked to the insertion of the researcher in the field called "immersibility". He/she will be participating in some form of care practice and will be directly involved with the research method, which implies a commitment to benefit the care context during the investigative process ${ }^{(24)}$.

The phenomenon of intertwining research assistance actions is called "convergence". It is the result of the complex existence of simultaneous movements between care and research, configuring a "dance", characterized by movements of approximation and removal that culminate in points of articulation, called"superposition spaces"(24). In this study, the PCA was used as a methodological reference due to the possibility of developing joint research and assistance actions in order to direct towards the minimization of problems and the introduction of innovations in care practices for women in situations of violence. The study was guided by the "consolidated criteria for reporting qualitative research" (COREQ).

\section{Methodological procedures}

\section{Study scenario}

The study was carried out in the city of Santa Maria, state of Rio Grande do Sul, Southern Brazil, from February to August 2015. The space for discussion was the Integrated Working Group to Combat Violence (IWGCV), linked to the Violence Observatory of a large hospital. The IWGCV is a space for dialogue about assistance to people in situations of violence, as well as about the functioning of each service and the composition of an integrated work. It is formed by health, social assistance, and public security professionals.

\section{Data source}

Ten meetings were held, and 32 people participated in the study, among which 3 were students from the Social Work or Psychology courses; and 29 were professionals: social workers, psychologists, nurses, nursing technicians, pharmacists, physicians, and police officers. The inclusion criteria were: being a member of the IWGCV, being able to be professional or academic.

\section{Data collection and organization}

Data production was conducted using the convergent group technique (CG) ${ }^{(24)}$, applied with the aim of implementing actions in care practice and making abstractions from it to build knowledge about the topic in question. This construction involved a process of interaction between the participants and the researcher, thus allowing for dialogicity, an attribute of the CCR that allows the participants to understand the unity between care and research, without mischaracterizing each one of them around the same phenomenon.

Data production was conducted using the convergent group technique (CG) ${ }^{(24)}$, applied with the aim of implementing actions in care practice and making abstractions from it to build knowledge about the topic in question. This construction involved a process of interaction between the participants and the researcher, thus allowing for dialogicity, an attribute of the CCR that allows the participants to understand the unity between care and research, without mischaracterizing each one of them around the same phenomenon $^{(25)}$.

The MP applied to the study (Figure 1), disclosed in our previous study, consisted of completing the five steps: 1) Reality observation and definition of the study problem: the disarticulation of care actions for women in situations of violence. At this stage, the participants spoke about their understanding of the network, as well as the facilitating and limiting aspects for the formation of a network of care; 2 ) Reflection on the problem and emergence of the key points: the points to be studied in the group were defined, that is, the legal recommendations about the network service and the construction of service flowcharts; 3 ) Theorization: educational practice was carried out, elaborated with the group, regarding the themes theorized in the previous stage; 4) Elaboration of hypotheses for solving the problem listed in step 1. The defined hypotheses were: the construction of a service flowchart to guide the services, as well as the creation of an instrument to mediate communication between them; 5) Application to the reality under study: exercising the learned solutions. Two products were collectively built, in order to contribute to the construction of the local network of care for women in situations of violence.

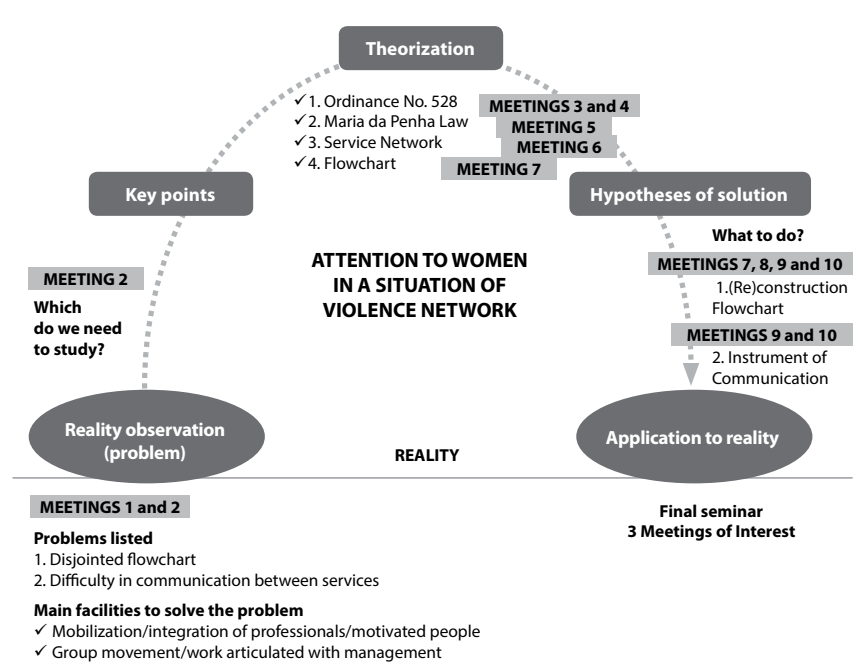

Figure 1 - Steps of the Problematization Methodology with the Arch of Maguerez applied in the on-screen study ${ }^{(26)}$

The meetings ended when the internal logic of the object of study was understood, which showed the meanings attributed by professionals and students to the construction of the service network for women in situations of violence through data saturation ${ }^{(27)}$; and also when possible solutions were built for the disarticulation of care services. 


\section{Data analysis}

To organize the data, the audios were transcribed and systematized and treated by thematic content analysis ${ }^{(28)}$. In the pre-analysis phase, the floating reading was carried out to approach the theme, followed by the material exploration phase to capture the nuclei of meaning in order to group ideas by affinity. Coding and categorization of findings were performed. The metaphorical meanings attributed by the participants were: the network is built by people, through a handmade work of sewing threads and tying knots. Thus, the nuclei of meaning composed the thematic category presented in this article: "The construction of the network is done by people through artisanal and intersectoral work". The last phase consisted of the treatment of results and their interpretation in the light of scientific production on care networks.

\section{RESULTS}

Considering that the CCR participants were predominantly female (31) and that the issue of violence against women is anchored in the unequal construction of gender, we chose to refer to female participants. Of these, 3 were students from Social Work or Psychology courses and 29 were professionals: social workers (5), psychologists (6), nurses (11), physicians (2), occupational therapist (1), pharmacist (1), speech therapist (1), nursing technician (1) and civil police (1). Regarding the level of education, 23 had a postgraduate degree, 5 had completed higher education, 1 had a technical course and 3 had completed high school. The time of experience in the sector ranged from less than 1 year to more than 20 years. The thematic category resulting from the thematic content analysis is described below.

\section{The construction of the network is done by people through artisanal and inter-sectorial work}

Participants discussed in the CG that the formation of the network has a metaphorical sense of being a craft work built by people in a continuous way and anchored in relationships. They alluded to the network made up of threads that need to be sewn and tied through contact with people, the care service professionals. They considered that, in order to be able to carry out the articulation, there is a need for the formation of bonds and partnerships between the services.

I understand network [...] which is made with moorings. And then I remember Gastão [sanitary doctor]: he talks about a certain craft work [...] sewing is handicraft. (P4/Hospital)

Over time, we build these professional relationships with people [...] this for me is a network, but it is a network of people holding hands. From committed people [...] it's a bond. [...] It is intersectorial [...] culture; justice enters. (P5/ Hospital)

It's that commitment. [...] To establish a network, it's about thinking about care and going through all the sectors that have to do with that problem. (P3/State Health Department)
The network is not ready, we are the ones who build it. We are the nodes of the network. So I have to tie my knot with someone. (P9/Municipal Health Department) The building of network and contacts that participants refer is about going beyond the referral to the other service and always having feedback. The network must be permeated by the communication/connection between the services - it would be the reference and counter-reference -, which requires knowing the work and the work process developed in each service.

Getting to know people, the institutions they work with, what they do, what my work has to do with hers and if she will be open to receiving what I have to send [the demand for the service]. (P5/ Hospital)

Contacts are very important [...] because the contact with people [...] has a channel within that institution. (P8/Precinct)

You make a referral and you don't have the counter-referral [...]. Did the referral I made work? I think it's important for us to have this feedback, this continuous exchange. (P7/ Hospital)

For the network, it needs to have a formal instrument, help, contacts. (P4/Hospital)

During the group meetings, the participants cite the services as the nodes of an intersectoral network that includes health, social assistance, education, culture, housing, work, infrastructure, sanitation, police, justice, among others.

It is inter-sectorial [...] culture enters; the Justice. (P5/ Hospital)

The Specialized Reference Center in Social Assistance [CREAS], education [...] often, they arrive at the school or the school can also contribute to this understanding of the case. And the Police Station. (P1/Municipal Health Department)

To establish a network, it's about thinking about care and going through all the sectors that have to do with that problem, because everyone has the knowledge that is fine-tuned. (P3/State Health Department)

It goes beyond health, to housing, planning, infrastructure. (P4/ Hospital)

She came forwarded [hospital clinic] by a nutrition professional [...] then contact was made with the network in a place close to the residence [...] the Social Assistance Reference Center [CRAS] which followed the follow-up, but it could be the CREAS. (P6/Hospital)

\section{DISCUSSION}

Among the meanings attributed by the participants to the service network for women in situations of violence (IPV), the network metaphorically designed in allusion to the fabric stands out, consisting of threads to be sewn and tied. Reflecting on the image of the network as an object, a continuity of intersecting and intertwining lines stands out; and, as they pass through the nodes, they create links between them, connections. This dependence between network lines and nodes is its very essence. There is no network without tightly interconnected lines. 
The network is characterized by the absolute dependence of all nodes on each other ${ }^{(23)}$. This understanding converges with the concept of "service network"(6), in which the nodes are the sectors, reaffirming the importance of inter-sectorality ${ }^{(29)}$.

However, the action in a network is not only given by the existence of a set of services, as in this way it can only be a sum of interventions of juxtaposed services, without necessarily occurring integration between them. When there is juxtaposition, it is considered more of a web of services than a network. In the network, the existence of articulation between the actions of each service is necessary, being essential the shared care production in order to build a common care project ${ }^{(29)}$.

The movement of comings and goings of women in services and the need for feedback announced by the participants reflect the permanence of limits in care and indicate the need to qualify communication for the formation of a network, which is articulated in an inter-sectorial way with a view to resoluteness attention to women and their families. The participants recognize the need to carry out work in an intersectoral network, which is in line with other studies with professionals in the areas of health, safety, justice and psychosocial care ${ }^{(20)}$, who see this network as a result of the integration of sectors and services ${ }^{(18,22,29)}$.

A study carried out with PHC professionals showed that they understand the need for interdisciplinarity and intersectoral work in health care. Even when the focus of attention to women was developed in a rural environment, the study participants understood the coping network as a "joint" work, based on the involvement of different sectors ${ }^{(22)}$.

The need for contact between the services was expressed by the study participants, which made it possible to infer that knowledge about the other services is partial. Many are still unaware of the functioning of the services that make up the service network for these women, as well as the importance of their articulation. The dynamics of working in a network presupposes that professionals know the services, their skills and the role of the network ${ }^{(29-30)}$.

Getting to know the other nodes of the network means appropriating the spaces. This knowledge produces bonds, cooperation and supports the development of prevention, notification, registration, referral and monitoring actions for women, favoring the continuity of care and increasing credibility in the services ${ }^{(19,30)}$. For health professionals, the knowledge of professionals who are members of the network facilitates coping with IPV(3). When they share each other's attributions, internal and external procedures, as well as service hours and their location, it is that the continuity of care can be carried out ${ }^{(29-30)}$.

The professional's lack of knowledge of the function of a given service can show difficulty in its inclusion as an alternative care. When the work of the other is not known, the realization of partnerships and sharing of common care projects is compromised ${ }^{(21,31-32)}$. In addition, isolation can be generated and the woman's critical route difficult, since she may be referred to places where she will not find answers to her needs. It is reinforced that, for there to be intersectoral integration, the first step is to build a dialogue between the services ${ }^{(29,31)}$.

Networks are formed by people and connections between them, as they are part of institutions; they are bonds and do not exist without professionals. Thus, it is not merely made up of administrative and bureaucratic relations between institutions ${ }^{(30)}$.
Working in a network presupposes sharing efforts, interaction and articulation between the services involved in the situation, developing joint actions ${ }^{(19,29)}$. However, women who seek professional care after experiencing a situation of violence mention the (dis)articulation between the network services ${ }^{(33-34)}$.

Attention is marked by the disarticulation between services, and a permanent work group could be a powerful space and trigger for this network movement. Thus, although inserted in a scenario of fragmentation of care, the participants recognized the potential for acting in a network. However, there is precariousness of investments, and there is little visibility of violence against women in the scope of services and in the management of public policies in the scenario in question.

To promote inter-sectorial articulation, management initiatives are essential, as they can enable interaction between the most diverse institutions. Continuous bonds are necessary, through, for example, work groups, spaces for meetings with representatives of different services, who can debate strategies for women's empowerment and coping with violence ${ }^{(19)}$. To this end, the institutions demand an adequate contribution of human resources, physical infrastructure, a favorable environment that allows them to form spaces of inter-sectorial communication for the design and construction of the network, as well as flexibility of agendas for the mobility of professionals.

In this study, the discussions were permeated by the perceived complexity of the follow-up of cases and the understanding of this as an essential factor, considering the continuity of care for women. This implies the effectiveness of all the steps that compose it: recognition of violence by professionals, adequate care, referral, interest and the search for the return of references ${ }^{(19)}$. Therefore, there is a need to overcome the porosity between services $^{(35)}$ and move towards the construction of the network, a work permeated by ties/seams.

It appears that the participants had appropriated the meaning of networking to face IPV. They highlighted the need to create interdisciplinary spaces, which is essential, as integrated efforts from different areas can enable a culture of work and inter-sectorial communication. They valued the dimensions of listening, welcoming and bonding in the care of women to develop network articulation. As concrete communication devices to break institutional barriers, the establishment of the care flowchart, contact, spoken and formalized communication were also highlighted. However, in addition to these devices, professional practice needs to go beyond isolated referencing, with an end in itself. Flowcharts can direct the continuity of care in different sectors, associated with an institutional system of efficient communication between them ${ }^{(17)}$.

The need for a sense of belonging in the services is understood, an issue that emerged in the discussions based on the metaphor of the network represented in the craft composition based on nodes, when the participants expressed themselves as part of the nodes of this network. In a network, there are ways of intersection, and management support, initiative and dialogic action with workers are needed. The potential of networking is related to the quality of connections and communications between professionals and services, knowledge of the sectors involved and accountability of professionals with a view to collective and shared action ${ }^{(22,29)}$. 
The linkages between the different sectors (health, social development, public security, and justice) need to be carried out through integration mechanisms, such as intersectoral groups, social control and women's movements. However, the National Policy to Combat Violence against Women ${ }^{(6)}$ and the Brazilian Unified Health System itself, which advocate care in an integrated network, hardly propose concrete mechanisms that indicate how to make this action feasible.

In health education, there is little space for learning and articulation experiences with other sectors. Studies show that the theme of violence itself is not actually addressed as part of the professional field in this area; and that, even when there is professional training in women's health, there is no guarantee of approaching the subject. There is little knowledge about the legislation, norms and protocols for assisting women in situations of violence ${ }^{(20)}$. This is even understandable since the pattern of training, in general, is fragmented, based on the biomedical model, and hardly dialogues with the social reality of women. This fact culminates in great difficulty in handling situations of emotional fragility and lack of protection, which are subjective issues. In addition, the professionals know little about other women's care services ${ }^{(36)}$.

There is an urgent need to include the topic in health and inservice training, as well as in other areas, so that teaching and service can create new strategies and innovative technological tools that contribute to the construction of the service network and the implementation of affirmative actions, communication mechanisms and inter-sectorial articulation coordinated by the municipalities. It reinforces the importance of collective and interdisciplinary spaces being incorporated in the planning of public policies to combat IPV or other services for women.

\section{Study limitations}

The limitation of this research is the need to include other professionals from different sectors who are involved in the care of women in situations of intimate partner violence, since the study was conducted with professionals representing the services and managers and students who participated in this WG. Communication problems for network articulation require the deepening of areas of information and communication technologies.

In addition, the study was limited by not presenting the trajectory of women in their critical routes in the search for help, since it was delimited based on the performance of service and management professionals. It points to a gap to be filled by further research on the subject in order to continue studies on the service network, based on the dynamics of women's lives. We recognize the local character of the research, but we reiterate that the immersibility and dialogicity as a basis in the city's reality, resources, potentials, and weaknesses for the construction of networks culminated in the production of data in a participatory and feasible way to reconstruct the context of care practice.

\section{Contributions to the field of Nursing, Health or Public Policy}

Violence against women is a public health problem and a violation of human rights. Since it is a complex issue, it must be tackled through work in an inter-sectorial network, in line with the Sustainable Development Goals proposed by Agenda 30-30. Networking is gradually being incorporated by health professionals, considering that the fragmentation of care and hierarchical models of care are still prevalent in Brazil. This scenario requires the expansion of care (centered on women's demands) and academic and professional practices in the context of health and in-service training.

Understanding the meanings of the network for professionals contributes to demarcating investments in permanent health education, since professionals in this area, especially nursing professionals, are potential agents for the identification and reception of women in situations of violence and can be activators of the interprofessional and networking work. In addition, this understanding points to the need for investments in intersectoral policies to address the problem.

\section{FINAL CONSIDERATIONS}

The metaphor of the network represents the construction of the service network for women in situations of violence, a composition that has as its essence the relational dimension, which implies the definition of lines that intertwine and the formation of nodes that create connections for the performance or for intersectoral work. Construction is a permanent movement, as there is a need for new seams and ties so that the network can be recomposed, based on the mobility of people in the sectors and on the unique demands of women.

We understand that, in order to overcome the traditional care model, it is necessary to recognize and encourage the discussion of the formation of the network in loco, in services, since there is no ready-made recipe for the construction of this work. It is essential to keep the reflection on the theme and incorporate it into the daily training of professionals (transcending the health area). There is a need to use operational mechanisms and information technologies for the continuity of care, in order to contribute to the assistance dimension of the network provided in public policies that support the theme.

Flowcharts are needed to direct the continuity of care in the different sectors, associated with the need for more spaces for intersectoral articulation and an institutional system of efficient communication between the different sectors involved. This implies overcoming the gap between what is thought, what is produced and what is recommended by public policies in terms of network formation.

\section{SUPPLEMENTARY MATERIAL}

Data deposited in Repositories: Cortes LF. Women in situations of violence: collective construction of instruments for the articulation of network care [thesis]. 2017 Jun 27 [cited 2021 Jan 15]. Source Manancial Digital Repository of Federal University of Santa Maria. Available from: https://repositorio.ufsm.br/handle/1/13674.

\section{FUNDING}

The present work was carried out with the support of the Coordination for the Improvement of Higher Education Personnel - Brazil (CAPES) - Financing Code 001, doctoral scholarship. 


\section{REFERENCES}

1. Saletti-Cuesta L, Ferioli A, Del Valle Martínez F, Viel E, Baudin V, Romero P, et al. El abordaje de la violencia de género desde la perspectiva de las comunidades del norte cordobés, Argentina. Cad Saude Publica. 2020;36(1):e00184418. https://doi.org/10.1590/0102-311x00184418

2. World Health Organization. Global and regional estimates of violence against women: prevalence and health effects of intimate partner violence and nonpartner sexual violence [Internet]. Geneva:WHO; 2013[cited 2020 Jun 05]. Available from: https://apps.who.int/iris/ bitstream/handle/10665/85239/9789241564625_eng.pdf;jsessionid=F0B2F121FE991C1A6B0124218AC6686B?sequence=1

3. Rojas Loría K, Fernández Sánchez A, Gutiérrez Rosado T. Barreras y facilitadores del abordaje de la violencia contra las mujeres: perspectivas profesionales entre Cataluña y Costa Rica. Poblac Salud en Mesoam. 2019; 17(1):1-26. https://doi.org/10.15517/psm.v17i1.37814

4. Senado Federal (BR). Violência doméstica e familiar contra a mulher: pesquisa DataSenado [Internet]. Brasília, DF: SF; 2017[cited 2020 Jun 05]. Available from: https://www12.senado.leg.br/institucional/datasenado/arquivos/ aumenta-numero-de-mulheres-que-declaram-ter-sofrido-violencia

5. Alsaleh A. Violence against Kuwaiti women. J Interpers Violence. 2020;13:886260520916280. https://doi.org/10.1177/0886260520916280

6. Presidência da República (BR), Secretaria de Políticas para as Mulheres. Política nacional de enfrentamento à violência contra as mulheres [Internet]. Brasília, DF: SPM; 2011 [cited 2020 Jun 05]. Available from: https://www12.senado.leg.br/institucional/omv/entenda-a-violencia/ pdfs/politica-nacional-de-enfrentamento-a-violencia-contra-as-mulheres

7. Ministério da Saúde (BR), Secretaria de Atenção à Saúde. Política nacional de atenção integral à saúde da mulher: princípios e diretrizes [Internet]. Brasília, DF: MS; 2004[cited 2020 Jun 05]. (Série C. Projetos, programas e relatórios). Available from: https://bvsms.saude.gov.br/ bvs/publicacoes/politica_nac_atencao_mulher.pdf

8. Instituto de Pesquisa Econômica Aplicada (BR). Atlas da violência: 2019 [Internet]. Brasília, DF: IPEA; 2019 [cited 2020 Sep 17]. Available from: https://www.ipea.gov.br/atlasviolencia/download/19/atlas-da-violencia-2019

9. D'Oliveira AF. Invisibilidade e banalização da violência contra as mulheres na universidade: reconhecer para mudar. Interface (Botucatu). 2019;23:e190650. https://doi.org/10.1590/interface.190650

10. Damra JK, Abujilban S. Violence against women and its consequences on women's reproductive health and depression: a Jordanian sample. J Interpers Violence. 2018;36(5-6):NP3044-NP3060. https://doi.org/10.1177/0886260518770649

11. Antoniou E. Women's experiences of domestic violence during pregnancy: a qualitative research in Greece. Int J Environ Res Public Health. 2020;17(19):7069. https://doi.org/10.3390/ijerph17197069

12. Grose RG, Chen JS, Roof KA, Rachel S, Yount KM. Sexual and reproductive health outcomes of violence against women and girls in lowerincome countries: a review of reviews. J Sex Res. 2021;58(1):1-20. https://doi.org/10.1080/00224499.2019.1707466

13. Lucena KDT, Vianna RPT, Nascimento JA, Campos HFC, Oliveira ECT. Association between domestic violence and women's quality of life. Rev Latino-Am Enfermagem. 2017;25:e2901. https://doi.org/10.1590/1518-8345.1535.2901

14. Cañete-Lairla M, Gil-Lacruz M. Psychosocial variables associated with verbal abuse as a form of intimate partner violence against women in a Spanish sample. J Aggress Maltreat Trauma. 2017;27(3):237-55. https://doi.org/10.1080/10926771.2017.1320343

15. Bui QN, Hoang TX, Le NTV. The effect of domestic violence against women on child welfare in Vietnam. Child Youth Serv Rev. 2018;94:70919. https://doi.org/10.1016/j.childyouth.2018.09.024

16. Soares JSF, Lopes MJM. Experiências de mulheres em situação de violência em busca de atenção no setor saúde e na rede intersetorial. Interface (Botucatu). 2018;22(66):789-800. https://doi.org/10.1590/1807-57622016.0835

17. Cortes LF, Padoin SMM, Kinalski DDF. Instrumentos para articulação da rede de atenção às mulheres em situação de violência: construção coletiva. Rev Gaucha Enferm. 2016;37(esp):e2016-0056. https://doi.org/10.1590/1983-1447.2016.esp.2016-0056

18. Arboit J, Padoin SMM, Vieira LB, Paula CC, Costa MC, Cortes LF. Health care for women in situations of violence: discoordination of network professionals. Rev Esc Enferm USP. 2017;51:e03207. https://doi.org/10.1590/s1980-220x2016113303207

19. Menezes PRM, Lima IS, Correia MC, Souza SS, Erdmann LA, Gomes PN. Enfrentamento da violência contra a mulher: articulação intersetorial e atenção integral. Saude Soc. 2014;23(3):778-86. https://doi.org/10.1590/S0104-12902014000300004

20. Batista KBC, Schraiber LB, D'Oliveira AFPL. Gestores de saúde e o enfrentamento da violência de gênero contra as mulheres: as políticas públicas e sua implementação em São Paulo, Brasil. Cad Saude Publica. 2018;34(8):e00140017. https://doi.org/10.1590/0102-311x00140017

21. Aguiar JM, D'Oliveira AFPL, Schraiber LB. Mudanças históricas na rede intersetorial de serviços voltados à violência contra a mulher: São Paulo, Brasil. Interface (Botucatu). 2020;24:e190486. https://doi.org/10.1590/Interface.190486

22. Borth LC, Costa MC, Silva EB, Fontana DGR, Arboit J. Network to combat violence against rural women: articulation and communication of services. Rev Bras Enferm. 2018;71(suppl 3):1287-94. https://doi.org/10.1590/0034-7167-2017-0044

23. Vermelho SC, Velho APM, Bertoncello V. On the concept of social networks and their researchers. Educ Pesqui. 2015;41(4):863-81. https:// doi.org/10.1590/s1517-97022015041612

24. Trentini M, Paim L, Silva DMGV. The convergent care research method and its application in nursing practice. Texto Contexto Enferm. 2017;26(4):e1450017. https://doi.org/10.1590/0104-07072017001450017 
25. Berbel NAN, Sánches Gamboa SA. A metodologia da problematização com o Arco de Maguerez: uma perspectiva teórica e epistemológica. Filos Educ. 2011;3(2):264-87. https://doi.org/10.20396/rfe.v3i2.8635462

26. Cortes LF, Padoin SMM, Berbel NAN. Problematization methodology and convergent healthcare research: praxis proposal in research. Rev Bras Enferm. 2018;71(2):471-6. https://doi.org/10.1590/0034-7167-2016-0362

27. Minayo MCS. Amostragem e saturação em pesquisa qualitativa: consensos e controvérsias. Rev Pesqui Qual [Internet]. 2017 [cited 2020 Jul 4];5(7):1-12. Available from: https://editora.sepq.org.br/index.php/rpq/article/view/82

28. Minayo MCS. O desafio do conhecimento: pesquisa qualitativa em saúde. São Paulo: Hucitec; 2014.

29. Schraiber LB, D'Oliveira AFP, Hanada H, Kiss L. Assistência a mulheres em situação de violência: da trama de serviços à rede intersetorial. Athenea Dig. 2012;12(3):237-54. https://doi.org/10.5565/rev/athenea/v12n3.1110

30. Vieira EM, Hasse M. Perceptions of professionals in an intersectorial network about the assistance of women in situation of violence. Interface (Botucatu). 2017;21(60):51-62. https://doi.org/10.1590/1807-57622015.0357

31. Bermudez KM, Siqueira-Batista R. "Many holes tied together with ropes": the concept of network for mental health professionals. Saude Soc. 2017;26(4):904-19. https://doi.org/10.1590/s0104-12902017170298

32. Bearzi PSS, Martins AB, Marchi RJ, Reser AR. Trilhas para o enfrentamento da violência contra a mulher. Rev Estud Fem. $2020 ; 28(3)$ :e60162. https://doi.org/10.1590/1806-9584-2020v28n360162

33. Santos WJ, Freitas MIF. Weaknesses and potencialities of the healthcare network for women in situations of intimate partner violence. REME. 2017;21:e-1048. https://doi.org/10.5935/1415-2762.20170058

34. Souza MAR, Peres AM, Fumincelli L, Lopes VJ, Mercês NNA, Wall ML. Women perception in situations of violence in formal support: scoping review. Esc Anna Nery. 2021;25(2):e20200087. https://doi.org/10.1590/2177-9465-ean-2020-0087

35. Scott $P$, Nascimento FS, Cordeiro R, Nanes G. Redes de enfrentamento da violência contra mulheres no sertão de Pernambuco. Rev Estud Fem. 2016;24(3):851-70. https://doi.org/10.1590/1806-9584-2016v24n3p851

36. Souza AAC, Cintra RB. Ethical conflicts and limitations of medical care for women victims of gender violence. Rev Bioet. 2018;26(1):77-86. https://doi.org/10.1590/1983-80422018261228 